\title{
Green Synthesis of Silver Nanoparticles using Strobilanthes flaccidifolius Nees. Leaf Extract and its Antibacterial Activity
}

asujata D. Wangkheirakpam, , 'Wangkheirakpam Radhapiyari Devi, ${ }^{\text {b}}$ Chingakham B Singh and ${ }^{2}$ Warjeet S. Laitonjam*

\author{
${ }^{a}$ Chemistry Department, Manipur University \\ Canchipur -795003, Imphal, Manipur, India \\ ${ }^{b}$ Department of Biotechnology, \\ Institute of Bioresources and Sustainable Development \\ Imphal-795001, Manipur \\ *warjeetlaitonjam@yahoo.co.in, warjeet@yahoo.com
}

\section{ABSTRACT}

The leaf extract of Strobilanthes flaccidifolius Nees. was used for the synthesis of silver nanoparticles through a green technique of synthesis. The nanoparticles was characterized by UV-VIS spectroscopy which proves the formation silver nanoparticles. FTIR (Fourier Transmission infra red spectroscopy) study was carried out to assess the biomolecule as indigo precursors, Energy dispersion X-ray analysis(EDX) data further proves it. EPR (Electron paramagnetic resonance technique) shows the free radical in silver neutral state and $\mathrm{XRD}(\mathrm{X}$-ray diffraction technique) also repots silver neutral formation.The morphology and the shape of the silver nanoparticles were determined by Scanning electron microscopy(SEM) and Tunneling electron microscopy (TEM). The nanoparticles adopted spherical morphology and the size ranging from $6 \mathrm{~nm}$ to $54.11 \mathrm{~nm}$ and average size was determined as $12.15 \pm 5.3 \mathrm{~nm}$. The nanoparticles had antimicrobial activity.

\section{Keywords}

Green synthesis; Strobilanthes flaccidifolius Nees. Silver nanoparticles; Indigo precursors; Antimicrobial activity.

\section{Council for Innovative Research}

\section{Journal: Journal of Advances in Chemistry}

Peer Review Research Publishing System

\author{
Vol. 8, No. 1 \\ editor@cirworld.com




\section{INTRODUCTION}

One of the most active areas of research in modern materials science is the field of nanotechnology. The synthesis of gold nanoparticles inside life plants in alfalfa roots demonstrated for the first time by Gardea-Torresday et al. [1]. Silver nanoparticles were synthesized from the same plant inside the plant [2]. Many other work on biosynthesis from plants were carried out in Aloe vera, Cinnamon camphora, Capsicum annum L, Medicago sativa, Brassica juncea, B. chicory and Cymbopogon flexuosus [3]. Mude et al. studied the extracellular synthesis of in vitro generated extract of Carica papaya for the synthesis of AgNPs. The formation of silver nanoparticles were reported when aqueous silver ions $\left(\mathrm{AgNO}_{3} 1 \mathrm{mM}\right)$ was reacted with callus extract [4]. Song and Kim studied the extracellular synthesis of metallic $\mathrm{AgNO}_{3}$ using five plant leaf extracts, viz Pine, Persimmon, Gingko, Magnolia and Plantanus. Stable $\mathrm{AgNO}_{3}$ nanoparticles ranging from $5-500 \mathrm{~nm}$ were formed by treating aqueous $\mathrm{AgNO}_{3}$ with the plant extracts acting as reducing agents [5]. Further polysaccharides (heparin, hyaluronic acid, chitosan, cellulose, starch, dextrose and alginic acid) and pure phytochemicals (aloin A, apiin, aloesin and guavanoic acid) were used to synthesis nanoparticles which had properties like the parent polysaccharides or phytochemicals [6]. The methanol and aqueous extracts of fruits of Pseudocydonia sinesis were used for synthesizing silver nanoparticles. The nanoparticles were characterized by Energy dispersive X-ray analysis, X-ray diffraction, Tunneling electron microscopy, FTIR and UV-VIS spectroscopy. The nanoparticles were found antimicrobial activity against Bacillus subtilis, Candida albicans, Escherichia coli, Staphylococcus aureus and Saccharomyces cerevicae. MTT assay showed cell inhibition and cytotoxic activity [7]. Stable, poly shaped silver, and gold nanoparticles were synthesized using leaf extract of Lonicera japonica [8]. Studies on improvement of the bioavailability of curcumin by PLGA nanoparticles in rats; were carried out [9]. Different sized silver nanoparticles were synthesized by simply varying reaction conditions with leaf extract of Bauhinia variegate [10]. Biomimetic synthesis of silver nanoparticles by aqueous extract of Azadirachta indica leaves was carried out [11]. Green synthesis of nanoparticles using leaf and seed extract of Syzygium cumini L. [12], Capsicum annuum L. extract [13] were tested. Germanium leaf assisted biosynthesis of silver nanoparticles was also studied [14]. Efficacy of silver nanoparticles against Sitophilus oryzae was studied [15] and in other research too. Antibacterial property of silver nanoparticles using Artocarpus heterophyllus Lam. seed extract, Tribulus terrestris and Cryphonectria sp. were investigated [16-18]. Cytotoxic effect of plant mediated silver nanoparticles using Morinda citrifolia root extract was performed [19]. It was seen that the antimicrobial and cytotoxic properties varied with the property of the capping of different plants. Silver nanoparticles were synthesized with different techniques using the extracts of Coleus aromaticus, carob, myrrh, Pine cone, banana peel, Mimusops elengi, Cochlospermum gossypium, Eucalyptus chapmaniana, Hibiscus cannabinus, Iresine herbstii, Ocimum sanctum, Prosopis juliflora and Ocimum tenuiflorum and all the nanoparticles exhibited antimicrobial activity [20-33]. The aim of study is the silver nanoparticle of Strobilanthes flaccidifolius Nees. and its antimicrobial activity.

\section{MATERIALS AND METHODS}

\subsection{Plant material and preparation of extract}

The freshly leaves weighing $5 \mathrm{~g}$ were collected in separate beakers. Then it was thoroughly rinsed with distilled water. The sample was heated in $200 \mathrm{~mL}$ of solution of $50 \%$ ethanol in water on a steam bath till appearance of brown coloration. This brown colored extract was cooled to room temperature and filtered using Whatman filter paper (no.42). This extract was taken as the stock solution.

\subsection{Synthesis}

Volume of stock solution $(40 \mathrm{~mL})$ was made to double by addition of distilled water. The solution was treated with $\mathrm{AgNO}_{3}$ solution $(20 \mathrm{~mL})$ and warmed on steam bath for approximately 10min till reddish brown colour precipitate was observed, allowed to cool at room temperature. The silver nanoparticles were collected by centrifugation process for 10 min at $150000 \mathrm{rpm}$, washed with distilled water and dried at $30^{\circ} \mathrm{C}$ in a closed oven [34].

\subsection{Characterization of nanoparticles}

\subsubsection{FTIR analysis}

FTIR data was recorded on a Shimadzu FTIR instruments. The sample was made into $\mathrm{KBr}$ pellet and the spectra were recorded. The FTIR data of both the raw extract as well as the silver nanoparticles formed was recorded.

\subsubsection{UV-VIS analysis}

For UV spectra the raw extract was diluted with $50 \%$ ethanol and $0.03 \mathrm{M} \mathrm{AgNO}_{3}$ in the ratio of $4: 1$. The solution was heated on a water bath for $5 \mathrm{~min}$. It was allowed to stand and the absorption was recorded in a Shimadzu UV-VIS spectrophotometer. Further four fold dilution was performed before recording the spectra. For comparison and confirmation of formation of silver nanoparticles, the spectrum of the raw extract was also recorded along with the solution of the nanoparticles.

\subsubsection{XRD analysis}

The XRD of the sample was loaded on a PAN analytical XPERT-PRO instrument. The spectra were recorded from 20 to 80,2 theta with step size [ ${ }^{\circ} 2 \mathrm{Th}$.] of 0.0500 . Anode Material was Cu, K-Alpha1 $[\AA]$ ]:1.54060. Generator settings were at $30 \mathrm{~mA}, 40 \mathrm{kV}$ with scan step time [s] was 2.0000, and divergence slit size was 0.9570 and receiving slit size [mm]: was 0.2000. The Bragg-Brentano focusing geometry was used. The pattern was compared with the patterns of International Centre of Diffraction Data (ICDD) database nearest matching pattern was found with silver with XPERT HIGHSCORE. 


\subsubsection{SEM analysis}

SEM images were recorded on FEI-QUANTA-250 electron microscope. The compound was adsorbed on a carbon sheet and loaded on the microscope. The sizes of particles were measured with the software IMAGE $\mathrm{J}$ and the average was calculated.

\subsubsection{EPR analysis}

Electron paramagnetic resonance (EPR) was recorded for free radical analysis on JEOL JES-FA200 ESR spectrometer with X-band microwave unit.

\subsubsection{EDX analysis}

The EDX analysis was performed on an EDAX Energy Dispersion X-ray spectrometer. The identification of the elemental constituents and estimation of the quantities were done without standard.

\subsubsection{TEM analysis}

For TEM analysis the compound was dispersed in ethylene glycol and measured with JEOL JEM-2100. The sizes of particles were measured with the software IMAGE J.

\subsection{Antimicrobial assay}

The antimicrobial activity was assessed by agar well diffusion method using $20 \mathrm{ml}$ of sterile Nutrient agar (NA) (Hi-Media) for testing the bacterial against Proteus mirabilis, Klebsiella pneumoniae, Escherichia coli, Salmonella paratyphi and Pseudomonas aeruginosa [35]. The sample was diluted in $5 \mathrm{mg} / \mathrm{ml}$ in DMSO. The dilutions of the sample concentration were deposited $20 \mu \mathrm{l}$ on the inoculated well and left for $10 \mathrm{~min}$ at room temperature for the extract diffusion. Negative control was $\mathrm{AgNO}_{3}$ solution. Ciprofloxacin (Hi-Media) for bacteria were served as positive control. The plates were inoculated with bacteria were incubated at $37^{\circ} \mathrm{C}$ for $24 \mathrm{hr}$. The experiment was repeated four times and the average results were recorded. The antimicrobial activity was determined by measuring the diameter of the inhibition zone around the well. The susceptibility of microbial was determined by minimum inhibitory concentration determination method [36]. The minimum inhibitory concentrations (MICs) of the sample were determined by serial dilution against the microorganisms. The minimum concentrations at which no visible growth were observed were defined as the MICs, which were expressed in $\mathrm{mg} / \mathrm{ml}$. The antimicrobial tests were calculated as a mean of three replicates and the SD was calculated using the software SPSS, version 10 (SPSS, Richmond, USA).

\section{RESULTS AND DISCUSSION}

\subsection{Synthesis}

Synthesis was performed with the introduction of $\mathrm{AgNO}_{3}$ into the raw extract.

\subsection{UV-VIS analysis}

When the raw extract was treated with $0.03 \mathrm{M} \mathrm{AgNO}_{3}$ in the ratio of $4: 1$ and treating as described in the method and recording the spectra at different intervals of time a band started appearing at $450 \mathrm{~nm}$ after keeping for $10 \mathrm{~min}$ which corresponded to the surface Plasmon resonance band of noble metal silver. After $30 \mathrm{~min}$ band started flattening as illustrated in figure1 [37].

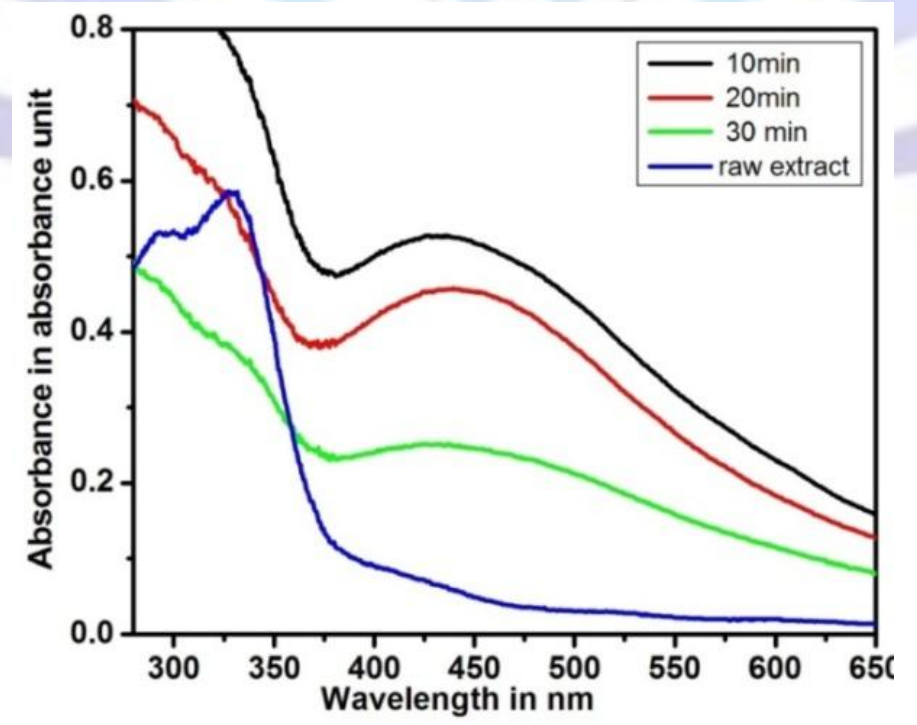

Figure 1. UV spectrum of silver nanoparticles composite of $S$. flaccidifolius at different interval of time 


\subsection{FTIR analysis}

FTIR measurements were carried out to identify the possible biomolecules responsible for reduction, capping and efficient stabilization of the $\mathrm{Ag}$ nanoparticles. The representative FTIR spectra of the S. flaccidifolius stabilized the silver nanoparticles (Figure 2) showing significant in their respective vibrational spectra where the crude methanol extract of $S$. flaccidifolius extract consisted of mainly the glucosides indican and isatan B which were indigo precursors [38]. Figure 2 showed the presence of three bands at 3300 to $2900 \mathrm{~cm}^{-1}, 1708 \mathrm{~cm}^{-1}, 1606 \mathrm{~cm}^{-1}$ and $1589 \mathrm{~cm}^{-1}$. The IR bands at $3300 \mathrm{~cm}^{-1}$ to $2900 \mathrm{~cm}^{-1}$ correspond to $\mathrm{OH}$ and small band at 3080 corresponds to $\mathrm{NH}$ strechings. The IR bands at $1708 \mathrm{~cm}^{-1}$ and $1606 \mathrm{~cm}^{-1}$ were characteristic of carbonyl group whereas the band at $1589 \mathrm{~cm}^{-1}$ was characteristic of $\mathrm{NH}_{-1}$ group respectively [39]. Band at $1508 \mathrm{~cm}^{-1}$ disappeared in the case of nanoparticles. Band at $761 \mathrm{~cm}^{-1}$ is because of $\mathrm{NH}$ wagging. These structural changes indicated that the reduction and stabilization of silver nanoparticles proceed via the coordination between $\mathrm{N}$ of the indigo precursors and silver ions. The FTIR studies had confirmed the fact that the hydroxyl and $\mathrm{N}$ form indigo precursors had the stronger ability to bind metal indicating that the glycosides could possibly form a layer covering the metal nanoparticles (i.e. capping of silver nanoparticles) to prevent agglomeration and thereby stabilized the medium.

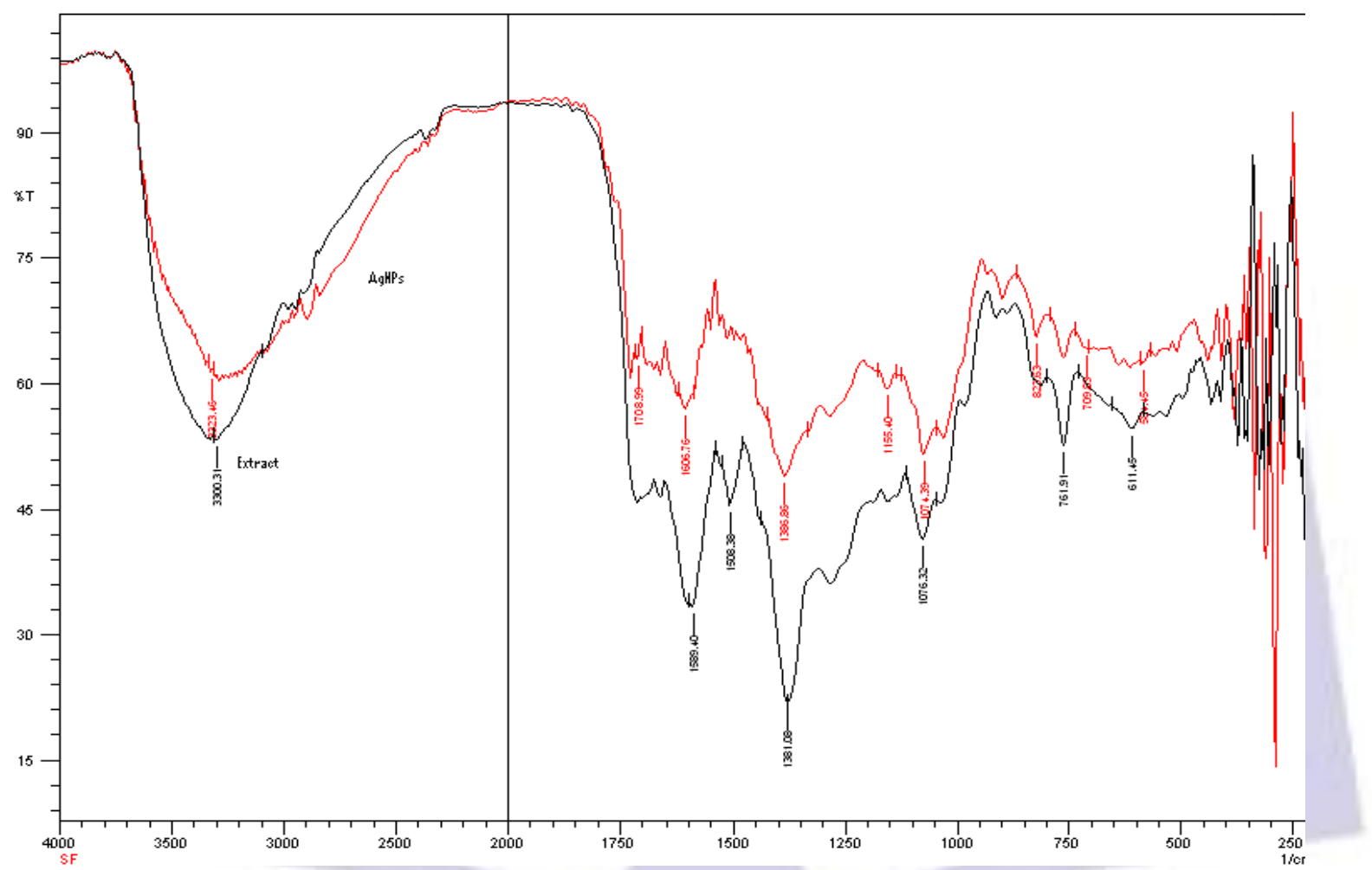

Figure 2. IR spectrum of crude extract and silver nanoparticles composite of $S$. flaccidifolius

\subsection{X-ray diffraction analysis}

The XRD pattern of the Ag nanoparticles prepared using S. flaccidifolius extract showed a number of strong Bragg reflections at 38.2, 44.3, 64.4 and 77.3 (Figure 3) which corresponded to the (1 1 1), (200), (2 20 ) and ( $\left.\begin{array}{lll}3 & 1 & 1\end{array}\right)$ facets of the face centered cubic crystal structure, respectively [40]. No diffraction peaks corresponding to the precursor $\left(\mathrm{AgNO}_{3}\right)$ and/or bi-products (such as silver oxide) were observed, which confirmed that only metallic $\mathrm{Ag}$ was formed by $\mathrm{S}$. flaccidifolius extract reaction. 


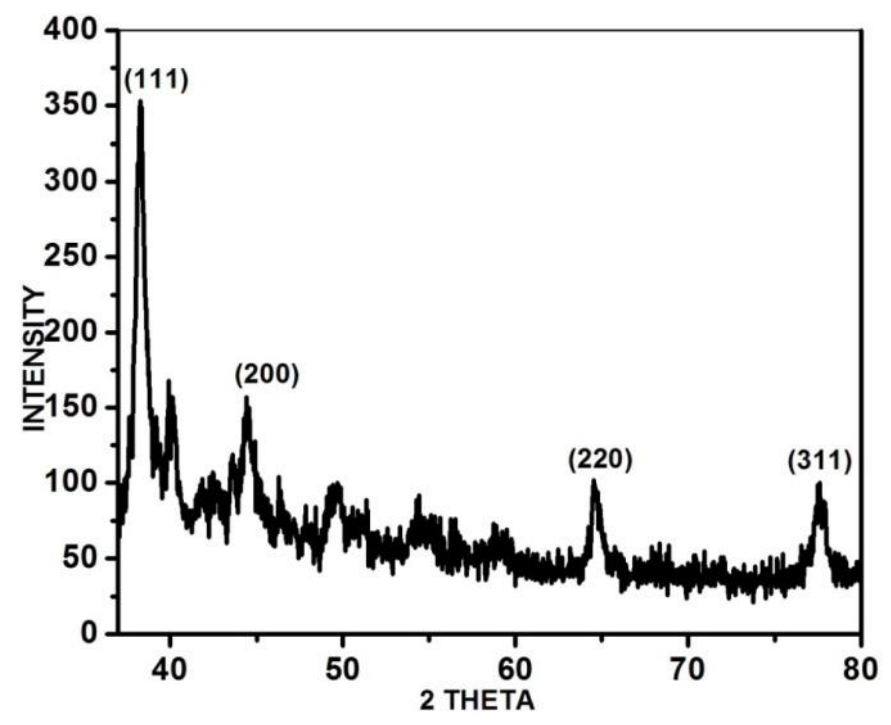

Figure 3. Powder XRD pattern of silver nanoparticles composite of S. flaccidifolius

Scanning Electron Microscopy (SEM) provided particle size analysis from the individual nanoparticles which was adopted spherical morphology (Figure 4) [41].

\subsection{Scanning Electron Microscopy}

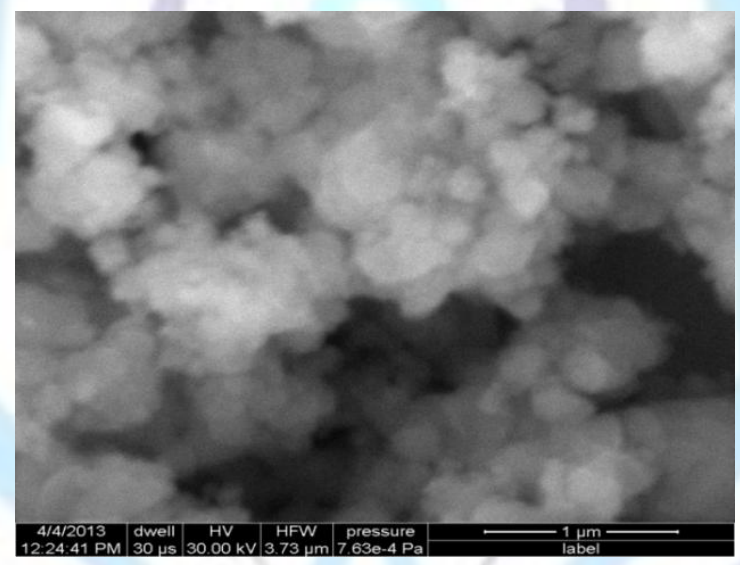

Figure 4. SEM images of AgNPs composite of $S$. flaccidifolius

\subsection{EDX identification and estimation}

The scanning SEM-EDX mapping images of the nanoparticles synthesized at different temperatures showed the presence of estimated elements (silver, carbon, oxygen, Nitrogen and Silver) (Figure 5). It also confirmed the formation of silver nanoparticles with the capping that reported earlier of indigo precursors and the formation of silver nanoparticles [42]. 
C:\}Usersłsupervisor|DesktopłsułAgSF-3.spc

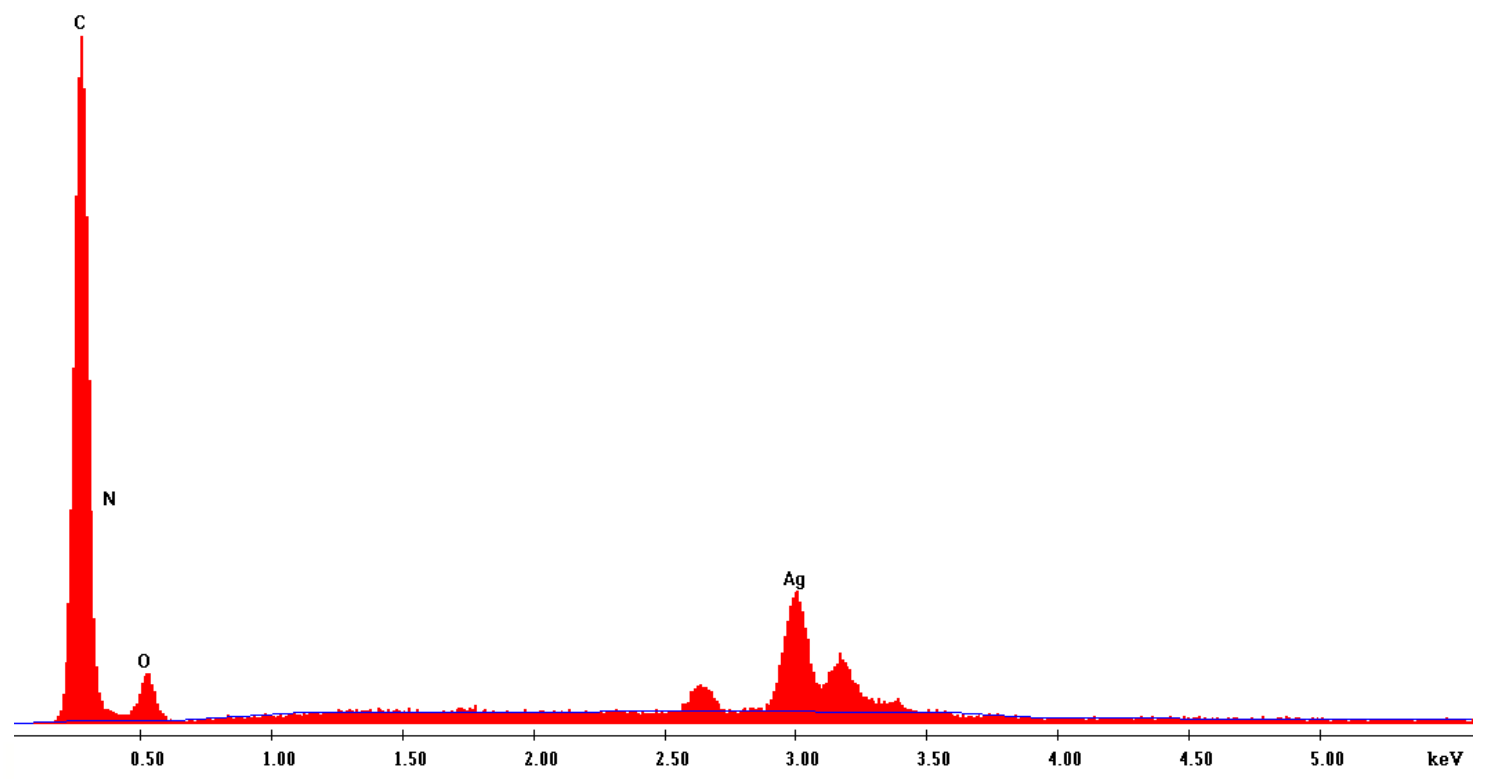

Figure 5. EDX spectrum of AgNPs composite of S. flaccidifolius

\subsection{EPR analysis}

The EPR signal showed the presence of lone pair indicating of the silver in neutral $d^{9}(A g 0)$ state which was absent in the $\mathrm{d}^{8}(\mathrm{Ag}+)$ state (Figure 6). This further proves the formation of silver nanoparticles.
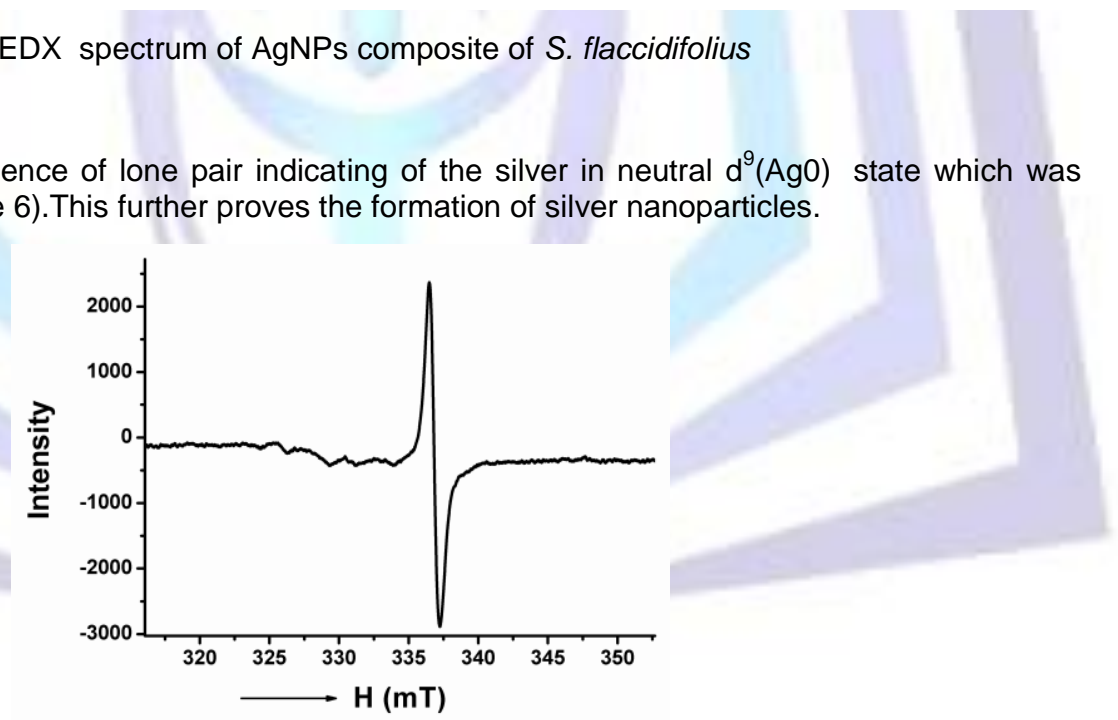

Figure 6. EPR spectrum of nano composite of $S$. flaccidifolius

\subsection{Transmission electron microscopy}

Spherical shaped particles were showed by TEM of the size ranging from $6 \mathrm{~nm}$ to $54.11 \mathrm{~nm}$ (Figure 7a). The average size was $12.15 \pm 5.3 \mathrm{~nm}$ in TEM image (Figure 7c). The SAED (Selected Area Electron Diffraction) pattern showed the miller planes of silver metal and additional peaks of the organic capping (Figure $7 \mathrm{~b}$ ) that proved the crystalline nature of the compound. The inter planar distance from the adjacent lattice fringes in HR-TEM image of one particle was $2.36 \AA \hat{~ w h i c h ~}$ corresponded to face centre cubic of Ag (Figure 7d). 


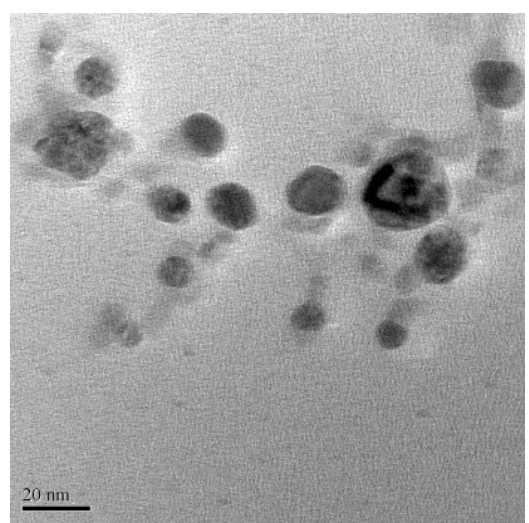

a) TEM image of AgNPs

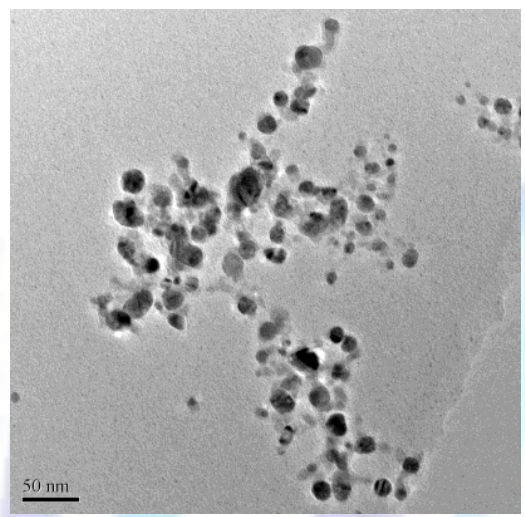

C) TEM image of AgNPs

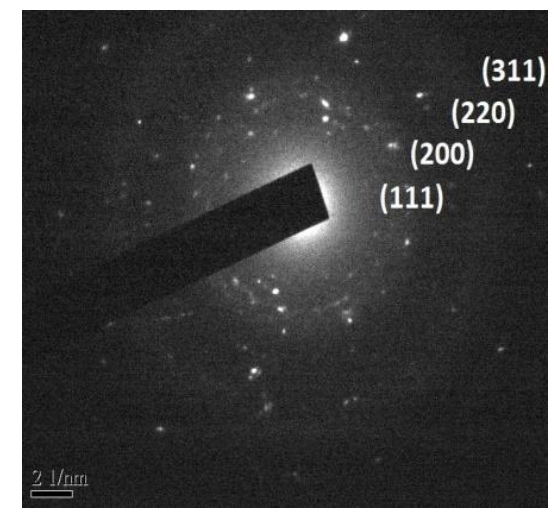

b) SAED pattern

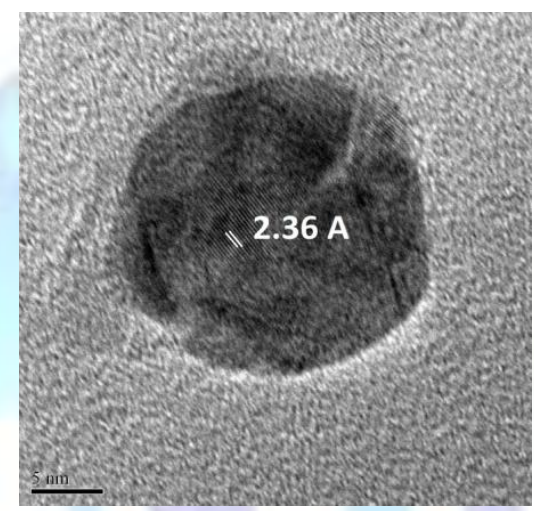

d) HRTEM image

Figure 7. TEM images of AgNPs composite of $S$. flaccidifolius

\subsection{Antimicrobial activity}

Antimicrobial effects of synthesized silver nanoparticles using S. flaccidifolius were tested. against human pathogens gram negative bacteria. The result showed inhibitory action when compared to silver nanoparticles at high level of zone of inhibition against $P$. aeruginosa. Moderate level of inhibitory activity was observed for $P$. mirabilis, K. pneumonia, E. coli and $S$. paratyphi. $P$. aeruginosa (MIC $=0.00122070312 \mathrm{mg} / \mathrm{ml}$ ) was found to be the most susceptible bacterial pathogen (Table 1). Crude silver blend shows potent activity than the purified silver nanoparticles, implies the bioactivity of combined plant and silver nanoparticles conjugate [43]. Exact antimicrobial effect of silver nanoparticles was still unclear, suggesting three different possible mechanism of action, involving first silver ions attach to the bacterial cell membrane and caused plasmolysis (cytoplasm of bacteria separated from bacterial cell wall), inhibited the bacterial cell membrane synthesis [44]. Secondly, AgNPs could strongly interact with sulphur-phosphorus containing compounds present inside (DNA, proteins) and outside (membrane proteins) of bacterial cell, affecting respiratory chain reaction, cell division and finally lead to cell death [45]. Finally, AgNPs released silver ions that will penetrate into the cell wall, causing condensation of DNA damage and also by affecting the protein synthesis [46]. Overall results showed the involvement of the phenomena of synthesized particles leading to the damage to pathogens or killing the pathogens. Raut et al. [47] investigated the antibacterial activity of photosynthesized silver nanoparticles against $E$. coli, $P$. aeroginosa and $K$. pneumoniae. Similarly, Kim et al. [48] reported antimicrobial activity of silver nanoparticles against $E$. coli and $S$. aureus. Kotakadi et al. [49] showed antibacterial activity of silver nanoparticles against E. coli. Sathishkumar et al. [50] inhibited antimicrobial activity of phyto-synthesis of silver nanoscale particles against $E$. coli, P. aeroginosa and K. Pneumonia. 
Table 1Inhibitory action of silver nanoparticles synthesized using the leaf extract of $S$. flaccidifolius against human pathogenic bacteria.

\begin{tabular}{|c|c|c|c|c|}
\hline \multirow[t]{2}{*}{ Microorganism } & \multirow{2}{*}{$\begin{array}{l}\text { Conc. } \\
(5 \mathrm{mg} / \mathrm{ml})\end{array}$} & \multicolumn{2}{|c|}{ Zone of inhibition (mm) } & \multirow{2}{*}{$\begin{array}{l}\text { MIC }(\mathrm{mg} / \mathrm{ml}) \\
\text { Silver } \\
\text { nanoparticles }\end{array}$} \\
\hline & & $\begin{array}{l}\text { Silver } \\
\text { nanoparticles }\end{array}$ & $\begin{array}{l}\text { Ciprofloxacin } \\
(100 \mu \mathrm{g} / \mathrm{ml})\end{array}$ & \\
\hline \multirow[t]{4}{*}{ Proteus mirabilis } & 5 & $26 \pm 0.06$ & $16 \pm 0.11$ & 0.009765625 \\
\hline & 2.5 & $24 \pm 0.31$ & & \\
\hline & 1.25 & $20 \pm 0.4$ & & \\
\hline & 0.625 & $18 \pm 0.21$ & & \\
\hline \multirow{4}{*}{$\begin{array}{l}\text { Klebsiella } \\
\text { pneumoniae }\end{array}$} & 5 & $26 \pm 0.08$ & $17 \pm 0.09$ & 0.009765625 \\
\hline & 2.5 & $24 \pm 0.12$ & & \\
\hline & 1.25 & $20 \pm 0.22$ & & \\
\hline & 0.625 & $18 \pm 0.05$ & & \\
\hline \multirow[t]{4}{*}{ Escherichia coli } & 5 & $20 \pm 0.14$ & $19 \pm 0.21$ & 0.01953125 \\
\hline & 2.5 & $18 \pm 0.11$ & & \\
\hline & 1.25 & $16 \pm 0.24$ & & \\
\hline & 0.625 & $14 \pm 0.15$ & & \\
\hline \multirow{4}{*}{$\begin{array}{l}\text { Salmonella } \\
\text { paratyphi }\end{array}$} & 5 & $26 \pm 0.8$ & $19 \pm 0.11$ & $<0.009765625$ \\
\hline & 2.5 & $22 \pm 0.4$ & & \\
\hline & 1.25 & $20 \pm 0.41$ & & \\
\hline & 0.625 & $18 \pm 0.02$ & & \\
\hline \multirow{4}{*}{$\begin{array}{l}\text { Pseudomonas } \\
\text { aeruginosa }\end{array}$} & 5 & $34 \pm 0.14$ & $20 \pm 0.08$ & 0.00122070312 \\
\hline & 2.5 & $30 \pm 0.22$ & & \\
\hline & 1.25 & $28 \pm 0.41$ & & \\
\hline & 0.625 & $24 \pm 0.24$ & & \\
\hline
\end{tabular}

\section{CONCLUSION}

The silver nanoparticles were synthesized with green technique using the extract of $S$. flaccidifolius as the reductant and the stabiliser. The formation of AgNPs was confirmed by IR, UV, EPR, EDX and XRD technique and size was characterized by SEM and HRTEM. The antimicrobial activity of the silver nanoparticles shows much potent inhibitory activity against clinically isolated pathogens. Hence the plant mediated synthesized nanoparticles can be used as good therapeutic agent against human pathogens and also for the successful development of drug delivery in near future.

\section{ACKNOWLEDGEMENT}

The authors acknowledge SAIF NEHU, Physics department Manipur University for TEM, SEM, EDX and Powder XRD data. Wangkheirakpam Sujata thank UGC, New Delhi for BSR Fellowship and for financial support.

\section{REFERENCES}

[1] J.L. Gardea-Torresdey, E. Gombez, J.G. Parsons, J. Peralta-Videa, P. Santiago, K.J Torresedey, S E. Troiani, J.S. Yacaman, Nano. Lett. 2 (2002) 19-26.

[2] J.L. Gardea-Torresdey, E. Gomez, J.S. Yacaman, J.G. Parsons, J. Peralta-Videa, H E. Troiani, Langmuir. 19(2003)1357-1361.

[3] S.R. Bonde, D.P., Rathod, A.P. Ingle, R.B., Ade, A.K., Gade, M..K. Rai. Nano science Methods 1(2012) 25-36.

[4] N. Mude, A. Ingle, A. Gade, M. Rai, J Plant Biochem. Biotechnol. 18(2009)83-86.

[5] J.Y Song, and B.S. Kim, Bioprocess Biosyst. Eng. 32 (2009) 79-84.

[6] Y.Park, Y.N. Hong, A. Weyers, Y.S. Kim, R.J. Linhardt, IET Nanoiotechnology (5) 3 (2011)69-78. 
[7] P.C. Nagajyothi, T.V.M. Sreekanth, D.L. Kap, Synthesis and Reactivity in Inorganic, Metal-Organic and Nano-Metal chemistry 42(2012)1339-1344.

[8] K. Vineet, K Y. Sudhesh. Int J Green Nanotechnology 3 (2011)281-291.

[9] X. Xiaoxia, T. Qing, Z. Yina, Z.Fengyi, G.Miao, W., Ying, W. Hui, Z. Qian, Y. Shuqin, J. Agric. Food Chem. 59(2011)9280-9289.

[10] V. Kumar, S.K. Yadav, I E T. Nanobiological 6(2011)1-8.

[11] A. Tripathy, A.M. Raichur, N. Chandrasekharan, T.C. Prathna, A. Mukherjee, J nanoparticle Res 12(2010)237-246.

[12] V. Kumar, SK. Yadav, Int J Green Nanotech. 3(2011)281-291.

[13] S. Li, Y. Shen, A. Xie, nX. Yu, L. Qiu, L. Zhang, Q. Zhang, Green Chemistry 9(2007) 852-858.

[14] S.S. Shankar, A. Ahmad, M. Sastry, Biotechnol Prog. 19(2003)1627-1631.

[15] A. Z. Abduz, A. Bagavan, C. Kamaraj, G. Elango, R. A., J Biopest. 5(2012)95 - 102.

[16] B.J. Umesh, A.B. Vishwas, Industrial crops and products. 46(2013)132-137.

[17] V. Gopinath, D. MubarakAli, S. Priyadarshini, N. M. Priyadharsshinia, N. Thajuddin, P. Velusamy, Colloids and Surfaces B: Biointerfaces 96 (2012) 69- 74.

[18] A. D. Mudasir, I. Avinash, R. Mahendra, Nanomedicine: Nanotechnology, Biology, and Medicine 9 (2013) 105-110.

[19] T.Y. Suman, S.R. Radhika Rajasree, A. Kanchana, S. Beena Elizabeth.Colloids and Surfaces B: Biointerfaces 106 (2013) 74- 78.

[20] V. Mahendran, A. Gurusam .Appl Nanosci. 3(2013)217-223.

[21] A.M.Awwad, M.S. Nida and O A. Amany. International J of Industrial Chemistry (2013) 4:29.

[22] I. M. El-Sherbiny, S. Ehab and M R. Fikry, J of Nanostructure in Chemistry (2013)3:8.

[23] V. Palanivel, L. Sang-Myung, I. Mahudunan, L. Kui-Jae, O. Byung-Taek .

Appl Microbiol Biotechnol. 97(2013)361-368.

[24] B. Ashok , J. Bhagyashree, R. K. Ameeta, Z. Smita.Colloids and Surfaces A: Physicochem. Eng. Aspects 368 (2010) 58-63.

[25] L. Anh-Tuan, P.T. Huy, P D Tam, T Q Huy, D C Phung, A.A. Kudrinskiy, Yu A. Krutyakov.Current Applied Physics 10 (2010) 910-916.

[26] P. Prakash, P. Gnanaprakasam, R. Emmanuel, S. Arokiyaraj, M. Saravanan Colloids and Surfaces B: Biointerfaces 108 (2013) 255-259.

[27] J. K. Aruna, R.B. Sashidhar, J. Arunachalam ${ }^{\mathrm{a}}$ Carbohydrate Polymers 82 (2010) 670-679.

[28] G. M. Sulaiman, W. H. Mohammed, T. R. Marzoog, A. A. Amir Al-Amiery, A.A. H. Kadhum, A. B. Mohamad, Asian Pac J Trop Biomed; 3(2013)58-63.

[29] M.R. Bindhu, M. Umadevi, Spectrochimica Acta Part A: Molecular and Biomolecular Spectroscopy 101 (2013) 184-190.

[30] C. Dipankar, S. Murugan, Colloids and Surfaces B: Biointerfaces 98 (2012) 112-119.

[31] Y. Subba Rao, Venkata S. Kotakadi, T.N.V.K.V. Prasad, A.V. Reddy , D.V.R. Sai Gopal, Spectrochimica Acta Part A: Molecular and Biomolecular Spectroscopy 103 (2013) 156-159.

[32] K. Raja, A. Saravanakumar, R. Vijayakumar.Spectrochimica Acta Part A: Molecular and Biomolecular Spectroscopy 97 (2012) 490-494.

[33] S. P. Rupali, R. K. Mangesh, S. K. Sanjay. Spectrochimica Acta Part A 91 (2012) 234-238

[34] A.K. Jha, K. Prasad, Int J Green Nanotechnology: Physics and Chemistry, 1(2010) 110-117.

[35] D.S. Reeves, I. Phillips, J.D. Williams, Laboratory methods in antimicrobial chemotherapy. Longman group Ltd, Edinburgh (1979)pp. 20.

[36] K.R. Cheruiyot, D. Olila, D Kateregga, Afri Health Sci, 9(2009)S42 - S46

[37] E. Rodriguez-Leon, R. Iniguez-Palomares, R. E. Navarro, R. Herrera-Urbina, J Tanori, C Iniguez-Palomares. A. Maldonado. Nanoscale Research Letters (2013) 8:318

[38] L.S. Warjeet, W. D. Sujata. Int J Plant Physiol and Biochem,;3(2011)108-116.

[39] M. Roni, K. Murugan, C. Panneerselvam, J. Subramaniam, H. Jiang-Shiou Parasitol Res 112 (2013)981-990 .

[40]M. F. Zayed, W. H. Eisa , A.A. Shabaka. Spectrochimica Acta Part A: Molecular and Biomolecular 
Spectroscopy 98 (2012) 423-428.

[41] V.Gopinath, D. MubarakAli, S. Priyadarshini, N. M. Priyadharsshini, N. Thajuddin, P. Velusamy. Colloids and Surfaces B: Biointerfaces 96 (2012) 69-74.

[42] Y. R. Subba, S. K.Venkata, T.N.V.KV.Prasad, A.V. Reddy, D.V.R. Sai Gopal Spectrochimica Acta Part A: Molecular and Biomolecular Spectroscopy 103 (2013) 156-159.

[43] D. MubarakAli, N. Thajuddin, K. Jeganathan, M. Gunasekaran, Colloids Surf. B: Biointerfaces 85 (2011) 360-365.

[44] J.R. Morones, J.L. Elechiguerra, A. Camacho, K. Holt, B. Juan Kouri, J.T. Ramrez, M.J. Yacaman, Nanotechnology 16 (2005) 2346-2353.

[45] H.Y. Song, K.K. Ko, I.H. Oh, B.T. Lee, Eur. Cells Mater. 11 (2006) 58.

[46] Q.L. Feng, J. Wu, G.Q. Chen, F.Z. Cui, T.N. Kim, J.O. Kim, J. Biomed. Mater. Res. 52 (2000) 662-668.

[47] W. Rout Rajesh, R. Lakkakula Jaya, S. Kolekar Niranjan, D. Mendhulkar Vijay, B. kashid Sahebrao, Curr. Nanosci. 5 (2009) 112-117.

[48] J.S. Kim, E. Kuk, K.N. Yu, J.H. Kim, S.J. Park, H.J. Lee, S.H. Kim, Y.K. Park, Y.H. Park, C.Y. Hwang, Y.K. Kim, Y.S. Lee, D.H. Jeong, M.H. Cho, Nanomed.: Nanotechnol. Biol. 3 (2007) 95-101.

[49] V. S. Kotakadi, Y. Subba Rao, Susmila Aparna Gaddam, T.N.V.K.V. Prasad, A. Varada Reddy, D.V.R. Sai Gopal, Colloids and Surfaces B: Biointerfaces 105 (2013) 194- 198.

[50] G. Sathishkumar, C. Gobinath, K. Karpagam, V. Hemamalini, K. Premkumar, S. Sivaramakrishnan, Colloids and Surfaces B: Biointerfaces 95 (2012) 235-240. 